\title{
PERANCANGAN ALAT INDUCSION HEATING PADA PENGOLAHAN TEH SANGRAI DENGAN TEKNOLOGI ENERGI TERBARUKAN (SOLAR CELL)
}

\author{
Evrita Lusiana Utari \\ Jurusan Teknik Elektro, Fakultas Sains \& Teknologi, Universitas Respati Yogyakarta \\ Jl. Laksda Adisucipto Km 6,3 Depok, Sleman, Yogyakarta 55281 \\ E-mail : evrita_lusiana@yahoo.com ${ }^{1}$
}

\begin{abstract}
Indonesia receives solar energy whose average daily energy radiation per unit area per unit time is about 4.8 kilowatts / m2. Solar energy is one of the most abundant, pollution-free, and optimally explored renewable energy sources. Indonesia located in the tropics is very suitable and has the potential to develop solar energy. In the utilization of solar energy, it is necessary to develop a technology capable of converting solar energy into the desired energy of electrical energy. The supply of electric energy during the day can still be controlled by solar cell, while at night controlled by Aki.

This technology is known as solar cells or internationally known as solar cell or photovoltaic. Induction heating is the onset of heat on the metal exposed to the induction of the magnetic field, this is because the metal arising Eddy current or navel currents in a circular direction surrounding the magnetic field occurrence of the navel due to the magnetic induction that cause magnetic flux that penetrates the metal, causing heat metal.

Designing Induction Heating Tool is a combination of solar cell technology with induction heating which benefits to the processing of tea production. This tool is able to induce the specimen so that the specimen becomes hot until it reaches the dry point reaches $100^{\circ} \mathrm{C}$. Power required to supply $300 \mathrm{Watt}$ heater.
\end{abstract}

Keywords : Solar Cell, Inductin Heating, Photovoltaic.

\section{PENDAHULUAN}

Energi merupakan aspek kehidupan yang kini menjadi sorotan manusia di seluruh dunia. Semakin menipisnya cadangan minyak bumi sebagai bahan bakar utama menyadarkan manusia untuk segera mencari alternatif pengganti yang bersifat terbarukan dan juga lebih ramah lingkungan. Salah satu sumber energi terbarukan yang belum dimanfaatkan dengan optimal adalah cahaya matahari. Indonesia yang terletak di khatulistiwa memiliki potensi penyinaran matahari yang luar biasa besar. Matahari bersinar selama 12 jam setiap hari, sepanjang tahun, dengan intensitas yang tinggi $4,8 \mathrm{kWH} / \mathrm{m} 2 /$ hari.

Menipisnya cadangan energi fosil di Indonesia dan kenyataan yang harus kita terima bahwa pemakaian energi berbahan dasar dari fosil telah menjadi salah satu penyebab terjadinya kelangkaan energi, maka sudah saatnya untuk menggalakkan pengembangan dan pemanfaatan energi terbarukan yang dimiliki. Indonesia memiliki potensi dan cadangan energi terbarukan yang besar, seperti tenaga matahari, panas bumi, dan air, termasuk lautan.

Pada pengembangan energi terbarukan di Indonesia untuk menggantikan energi konvensional ditandai dengan banyak pengembangan energi alternatif untuk menggantikan energi konvensional, seperti: pembangunan PLTU, PLTS, dan PLTA yang menggantikan pembangkit listrik berasal dari bahan bakar minyak dan batu bara. Indonesia mengoptimalkan pengembangan sumber energi alternatif supaya mengurangi ketergantungan terhadap sumber energi yang tak dapat diperbaharui (fosil). 
Indonesia menerima energi surya yang radiasi energi harian rata - rata per satuan luas per satuan waktu sebesar kira - kira 4,8 kilowatt $/ \mathrm{m}^{2}$. Energi surya adalah salah satu sumber energi terbarukan yang melimpah, bebas polusi dan dapat dieksplorasi secara optimal. Indonesia yang terletak didaerah tropis sangat cocok dan berpotensi dalam mengembangkan energi surya. Dalam pemanfaatan energi surya, perlu dikembangkan suatu teknologi yang mampu mengubah energi matahari menjadi energi yang diinginkan yakni energi listrik. Teknologi ini dikenal dengan istilah sel surya atau dalam dunia internasional lebih dikenal dengan solar cell atau photovoltaic.

Sel surya adalah piranti untuk mengubah energi matahari menjadi energi listrik. Energi listrik tersebut diperoleh dari sel surya yang menerima cahaya langsung dari matahari dan memunculkan efek fotovoltaik. Efek fotovoltaik pertama kali ditemukan oleh Edmond Becquerel pada tahun 1839. Pada tahun 1912 Einstein menjelaskan secara teori mekanisme fenomena tersebut namun hanya sebatas eksperimen dilaboratorium. Teknologi sel surya telah mengubah cara pandang manusia terhadap energi dan memberi solusi baru bagi manusia untuk memperoleh energi listrik tanpa perlu membakar bahan bakar fosil sebagaimana pada minyak bumi, gas alam, dan batu bara serta tidak pula dengan menempuh jalan reaksi fisi nuklir. Berkembangnya teknologi sel surya ini tidak terlepas dari kemajuan teknologi semikonduktor.

\section{TINJAUAN PUSTAKA}

Berdasarkan penelitian yang berjudul prototype pemanfaatan solar cell sebagai sumber energi pada sistem otomatisasi lampu penerangan taman oleh (W. Yossie, 2013). Perancangan dan pembuatan lampu penerangan taman otomatis terdiri dari beberapa komponen penting antara lain catu daya, solar cell, sistem minimum, lampu dan LCD. Prinsip kerja dari lampu penerangan taman otomatis adalah mendeteksi adanya tegangan yang dihasilkan solar cell dalam pengkonversian energi. Besar tegangan tersebut digunakan sebagai acuan untuk menyalakan atau mematikan lampu secara otomatis. Timer hanya bekerja ketika sensor cahaya (solar cell) terjadi gangguan dengan waktu selama 1 jam, selebihnya sensor cahaya yang bekerja untuk mengotomatisasi lampu. Unjuk kerja dari alat, ketika malam hari semua beban pada alat dalam kondisi aktif $(O N)$, sehingga arus yang mengalir sekitar $270 \mathrm{~mA}$. Suplai energi listrik saat siang hari masih dapat dikontrol oleh solar cell, sedangkan dimalam hari dikontrol oleh baterai $\mathrm{Li}$-Po $3600 \mathrm{mAH}$. Baterai tersebut dapat bertahan untuk suplai energi listrik pada malam hari, yaitu sekitar 14 jam, namun yang dibutuhkan hanya 12 jam maka dapat dikatakan cukup untuk menyuplai energi pada alat.

Berdasarkan penelitian (Faslucky, 2012), optimalisasi tegangan keluaran dari solar cell menggunakan lensa pemfokus cahaya matahari studi optimalisasi tegangan keluaran dari solar cell menggunakan lensa pemfokus cahaya matahari (lensa konvergen) bertujuan untuk mengetahui sebarapa besar pengaruh penggunaan lensa terhadap peningkatan nilai intensitas cahaya dan tegangan yang dihasilkan oleh solar cell, solar cell merupakan converter energi cahaya menjadi energi listrik. Solar cell yang digunakan dalam penelitian ini adalah solar cell jenis policrystal dan amorphous. Metode penelitian dilakukan dengan cara mengukur nilai intensitas, voltase dan arus listrik dari solar cell, kemudian menghitung nilai daya dan efisiensi dari solar cell dan membandingkan nilainya antara solar cell yang menggunakan lensa konvergen dan yang tidak menggunakan lensa konvergen. Berdasarkan hasil data penelitian, lensa konvergen mempengaruhi besarnya daya dari cahaya yang digunakan, sehingga intensitas dan energi cahaya meningkat dan mempengaruhi nilai voltase dan arus listrik dari solar cell. Untuk solar cell jenis policrystal efisiensi dapat ditingkatkan 
sampai $35.08 \%$. Kemudian untuk solar cell jenis amorphous dapat ditingkatkan sampai $31.77 \%$.

Menurut (Noviansyah,2013), yang mengambil penelitian tentang pemanas induksi kapasitas 200 Watt yang disebabkan karena pada logam timbul arus eddy yang arahnya melingkar melingkupi medan magnet terjadinya arus pusar akibat dari induksi magnet yang menimbulkan fluks magnetik yang menembus logam, sehingga menyebabkan panas pada logam. Untuk membuat pemanas induksi diperlukan suatu alat yang mampu menghasilkan energi listrik yang besar. Alat ini mampu menginduksi specimen tersebut sehingga specimen menjadi panas hingga mencapai titik cairnya. Titik cair dari specimen ini bernilai $\pm 660{ }^{\circ} \mathrm{C}$.

\subsection{Solar Cell}

Solar cell atau Panel Surya adalah alat untuk mengkonversikan tenaga matahari menjadi energi listrik. Photovoltaic adalah teknologi yang berfungsi untuk mengubah atau mengkonversi radiasi matahari menjadi energi listrik secara langsung. PV biasanya dikemas dalam sebuah unit yang disebut modul. Dalam sebuah modul surya terdiri dari banyak sel surya yang bisa disusun secara seri maupun paralel. Sedangkan yang dimaksud dengan surya adalah sebuah elemen semikonduktor yang dapat mengkonversi energi surya menjadi energi listrik atas efek photovoltaic. Solar cell dapat dilihat pada gambar 1 .

\subsection{Prinsip Dasar Teknologi Solar Cell (Photovoltaic) Dari Bahan Silokon}

Solar cell merupakan suatu perangkat semi konduktor yang dapat menghasilkan listrik jika diberikan sejumlah energi cahaya. Proses penghasilan energi listrik terjadi jika pemutusan ikatan elektron pada atom-atom yang tersusun dalam Kristal semikonduktor ketika diberikan sejumlah energi. Salah satu bahan semikonduktor yang biasa digunakan sebagai sel surya adalah kristal silikon.

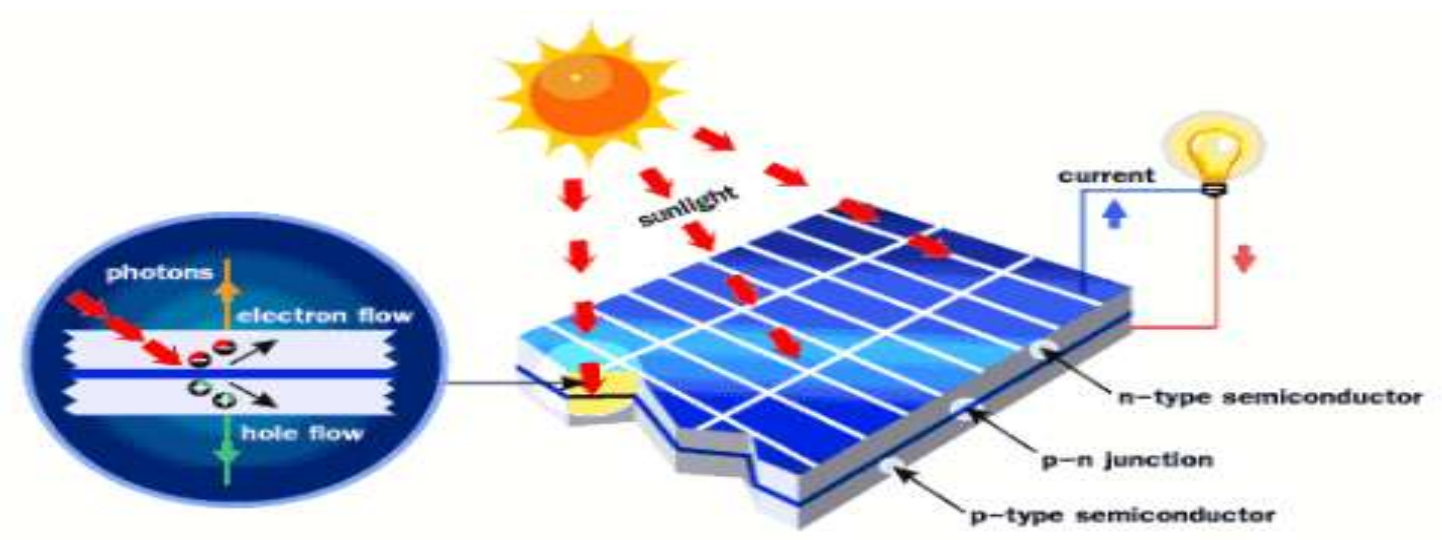

Gambar 1. Skema Solar Cell.

(Sumber: http://trebuchet-magazine.com/wp-content/uploads/2013/02/solar-cells.jpg)

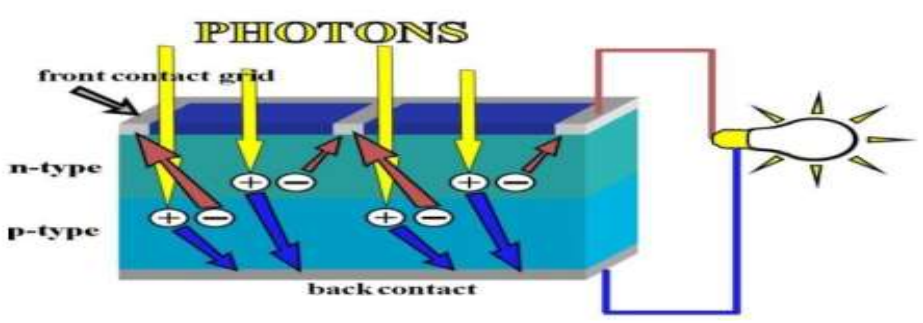

Gambar 2. Cara Kerja Solar Cell.

(Sumber : http://energisurya.files.wordpress.com/2007/solar-cell.jpg) 


\subsection{Semikonduktor Tipe $\mathbf{P}$ dan Tipe $\mathbf{N}$}

Ketika suatu Kristal silikon ditambahkan dengan unsur golongan kelima, misalnya arsen, maka atom - atom arsen itu akan menempati ruang diantara atom - atom silicon yang mengakibatkan munculnya elektron bebas pada material campuran tersebut. Elektron bebas tersebut berasal dari kelebihan elektron yang dimiliki oleh arsen terhadap linkungan sekitarnya, dalam hal ini adalah silicon. Semikonduktor jenis ini kemudian diberi nama semikonduktor tipen. Hal yang sebaliknya terjadi jika Kristal silicon ditambahkan oleh unsur golongan ketiga, misalnya boron, maka kurangnya elektron valensi boron dibandingkan dengan silicon mengakibatkan munculnya hole yang bermuatan positif pada semikonduktor tersebut. Semikonduktor ini dinamakan semikonduktor tipe-p. Adanya tambahan pembawa muatan tersebut mengakibatkan semikonduktor ini akan lebih banyak menghasilkan pembawa muatan ketika diberikan sejumlah energi tertentu, baik pada semikonduktor tipe-n maupun tipe-p.

\subsection{Sambungan P-N}

Ketika semikonduktor tipe-p dan tipe-n disambungkan maka akan terjadi difusi hole dari tipe-p menuju tipe-n dan difusi elektron dari tipe-n menuju tipe-p. Difusi tersebut akan meninggalkan daerah yang lebih positif pada batas tipe-n dan daerah lebih negatif pada batas tipe-p. Adanya perbedaan muatan pada sambungan $\mathrm{p}-\mathrm{n}$ disebut dengan daerah depresi akan mengakibatkan munculnya medan listrik yang mampu menghentikan laju difusi selanjutnya. Medan listrik tersebut mengakibatkan munculnya arus drift. Arus drift yaitu arus yang dihasilkan karena kemunculan medan listrik. Namun arus ini terimbangi oleh arus difusi sehingga secara keseluruhan tidak ada arus listrik yang mengalir pada semikonduktor sambungan $\mathrm{p}-\mathrm{n}$ tersebut. Sebagaimana yang kita ketahui bersama, elektron adalah partikel bermuatan yang mampu dipengaruhi oleh medan listrik. Kehadiran medan listrik pada elektron dapat mengakibatkan elektron bergerak. Hal inilah yang dilakukan pada solar cell sambungan p-n, yaitu dengan menghasilkan medan listrik pada sambungan $\mathrm{p}$-n agar elektron dapat mengalir akibat kehadiran medan listrik tersebut. (Sumber http://energisurya.files.wordpress.com).
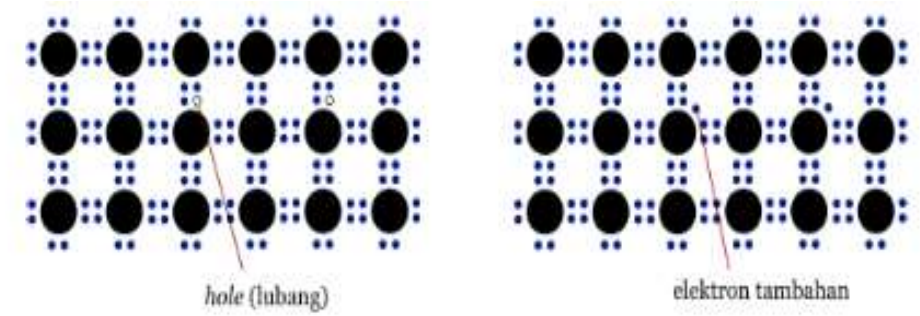

Gambar 3. Semikonduktor Tipe-P (Kiri) dan Tipe-N (Kanan).

(Sumber : Ady Iswanto, Staf Divisi Riset 102FM ITB, 2008)

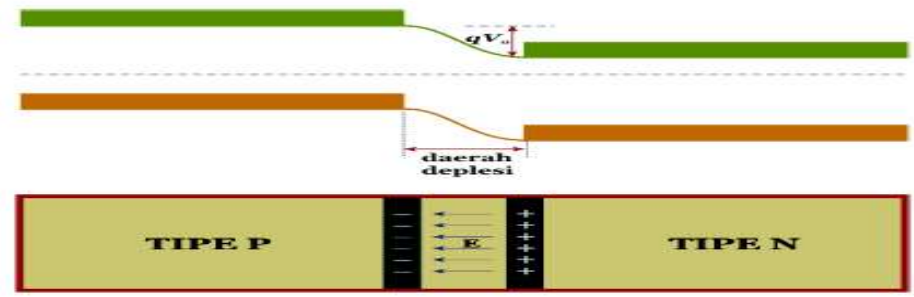

Gambar 4. Diagram Energi Sambungan P-N Munculnya Daerah Deplesi. (Sumber : Ady Iswanto, Staf Divisi Riset 102FM ITB, 2008) 


\subsection{Prinsip Dasar Solar Cell (Photovoltaic) Dari Bahan Tembaga}

Photovoltaic berdasarkan bentuk dibagi dua, yaitu photovoltaic padat dan photovoltaic cair. Photovoltaic cair prinsip kerjanya hampir sama dengan prinsip elektrovolt, namun perbedaanya tidak adanya reaksi oksidasi dan reduksi secara bersamaan (redoks) yang terjadi melainkan terjadinya pelepasan elektron saat terjadi penyinaran oleh cahaya matahari dari pita valensi (keadaan dasar) ke pita konduksi (keadaan elektron bebas) yang mengakibatkan terjadinya perbedaan potensial dan akhirnya menimbulkan arus.Pada solarcell cair dari bahan tembaga terdapat dua buah tembaga yaitu tembaga konduktor dan tembaga semikonduktor. Tembaga semikonduktor akan menghasilkan muatan elektron negatif jika terkena cahaya matahari, sedangkan tembaga konduktor akan menghasilkan muatan elektron positif.
Karena adanya perbedaan potensial akhinya akan menimbulkan arus.

\subsection{Instalasi Solar Cell Dengan Sistem Seri Solar Cell}

Hubungan seri suatu sel surya didapat apabila bagian depan $(+)$ sel surya utama dihubungkan dengan bagian belakang (-) sel surya kedua (Owen Bishop, 2004). Hubungan seri dari sel surya dapat dilihat pada gambar 6. Tegangan sel surya dijumlahkan apabila dihubungkan seri satu sama lain.

$U$ total $=\mathrm{U} 1=\mathrm{U} 2=\mathrm{U} 3=\mathrm{Un}$.

Arus yang timbul dari hubungan ini langsung dijumlahkan.

Itotal $=\mathrm{I} 1=\mathrm{I} 2=\mathrm{I} 3=\mathrm{In}$.

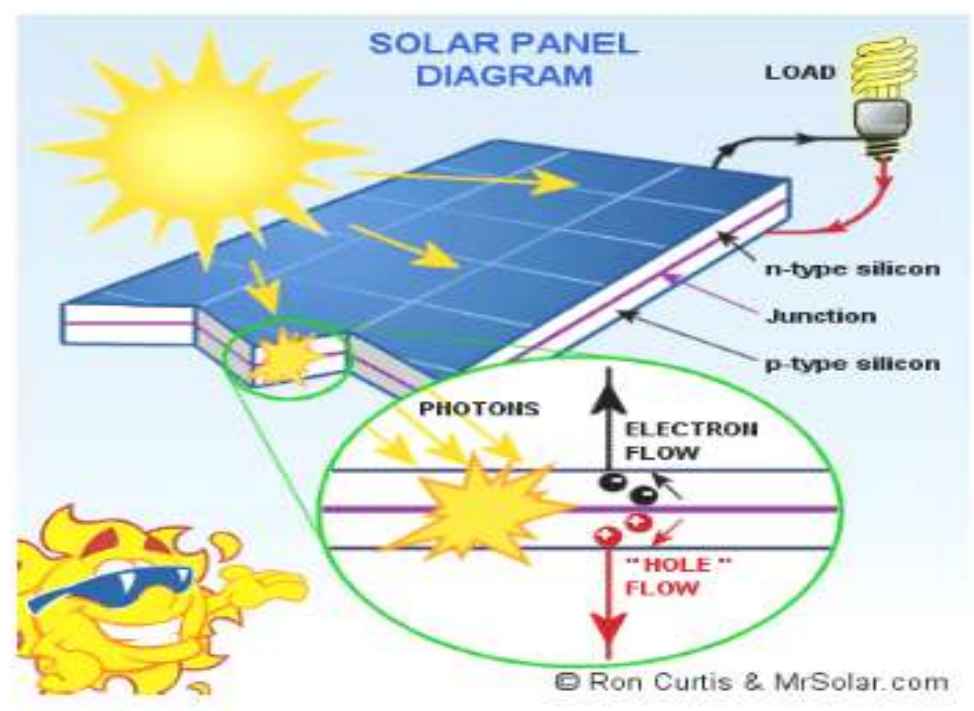

Gambar 5. Struktur Solar Cell Silikon p-n Junction. (Sumber: http://solarcell.com.jpg)

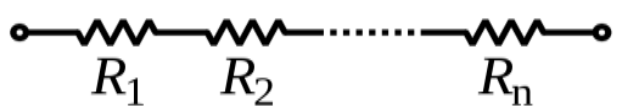

Gambar 6. Hubungan Seri.

(Sumber : http://elektronikadasar.wordpress.com.jpg) 


\subsection{Instalasi Solar Cell Dengan Sistem Pararel Solar Cell}

Rangkaian parallel solar cell didapat apabila terminal kutub positif dan negatif solar cell dihubungkan satu sama lain (Owen Bishop, 2004). Hubungan parallel dari solar cell dapat dilihat pada gambar 7 . Tegangan solarcell yang dihubungkan parallel sama dengan satu solar cell.

$U$ total $=\mathrm{U} 1=\mathrm{U} 2=\mathrm{U} 3=\mathrm{Un}$

Arus yang timbul dari hubungan ini langsung dijumlahkan.

Itotal $=\mathrm{I} 1+\mathrm{I} 2+\mathrm{I} 3+\mathrm{In}$.

\subsection{Modul Surya / Photovoltaik (Pv)}

Modul sel surya photovoltaik merubah energi surya menjadi arus listrik DC. Arus listrik DC yang dihasilkan ini akan dialirkan melalui Solar Charger Controler (PWM). Komponen utama sistem surya fotovoltaik adalah modul yang merupakan unit rakitan beberpa sel surya fotovoltaik. Modul fotovoltaik tersusun dari beberpa sel fotovoltaik yang dihubungkan secara seri dan paralel. Biaya yang dikeluarkan untuk membuat modul sel surya sebesar $30 \%$ dari biaya total. Lima hal utama yang mempengaruhi performasi dari modul fotovoltaik:

1. Bahan pembuatan Photovoltaic.

2. Resistansi beban.

3. Intensitas cahaya matahari.

4. Suhu / temperatur Modul Photovoltaic.

5. Bayangan.

\subsection{Solar Charger Controller (PWM)}

Solar Charger Controller adalah peralatan elektronik yang digunakan untuk mengatur arus searah yang diisi ke baterai dan diambil dari baterai ke beban. Solar Charger Controller mengatur kelebihan pengisihan karena baterai sudah penuh. Solar Charger Controller menerapkan teknologi Pulse Width Modulation (PWM) untuk mengatur fungsi pengisian baterai dan pembebasan arus dari baterai ke beban.

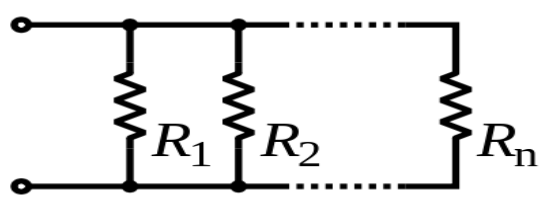

Gambar 7. Hubungan Parallel.

(Sumber : http://elektronikadasar.wordpress.com.jpg)

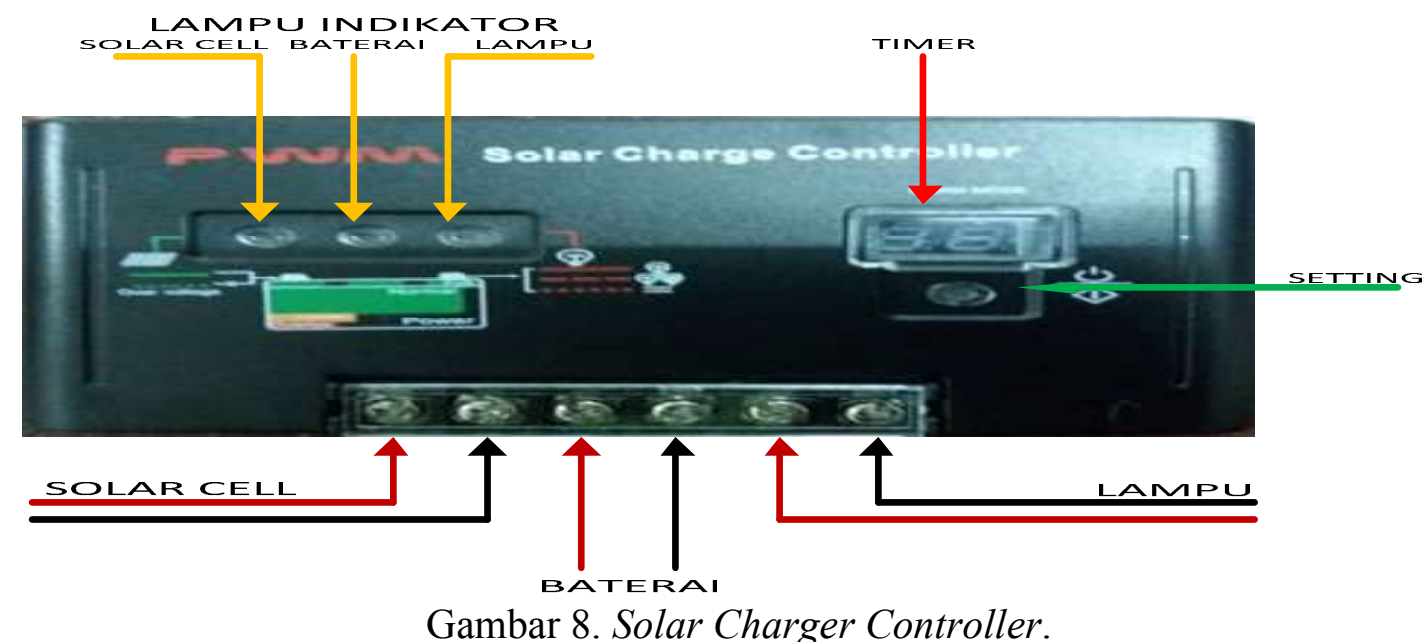

Gambar 8. Solar Charger Controller. 


\subsection{Baterai / Aki}

Baterai / Aki yaitu alat penyimpan energi listrik, dapat menyimpan energi listrik dalam satuan WattJam. Aki yang digunakan untuk penyimpan daya / sumber daya dengan spesifikasi aki kering merk panasonic dengan keluaran 12 Volt $100 \mathrm{Ah}$. Ukuran atau dimensi 407 x 173 x $236 \mathrm{~mm}$ dengan berat $31 \mathrm{~kg}$. Sebuah aki dengan kapasitas 12 Volt, 7,2 Ampere, berarti aki tersebut memiliki kapasitas $12 \times 7,2=86,4$ WattJam, artinya apabila kita menggunakan beban pemanas sebesar 300 Watt, membutuhkan jumlah aki yang sebanyak 8 buah dengan kapasitas 12 Volt, 7,2 Ampere. Dengan pemasangan aki diparalel maka kapasitas daya menjadi 691,2 Watt. Aki di bagi dalam 2 jenis yaitu aki basah dan aki kering.

\subsection{Induction Heating}

Pemanas induksi adalah timbulnya panas pada logam yang terkena induksi medan magnet, hal ini disebabkan karena pada logam timbul arus $e d d y$ atau arus pusar yang arahnya melingkar melingkupi medan magnet terjadinya arus pusar akibat dari induksi magnet yang menimbulkan fluks magnetik yang menembus logam, sehingga menyebabkan panas pada logam. Induksi magnet adalah kuat medan magnet akibat adanya arus listrik yang mengalir dalam konduktor.

Pemanasan Induksi juga disebut sebagai proses pemanasan non kontak yang menggunakan listrik frekuensi tinggi untuk menghasilkan panas yang konduktif secara elektrik. Karena non kontak, proses pemanasan tidak mencemari bahan yang sedang dipanaskan. Hal ini juga sangat efisien karena panas yang sebenarnya dihasilkan didalam benda kerja. Sehingga emanas induksi cocok untuk beberapa aplikasi yang unik dalam industri.

\subsection{Pemanas, Kabel dan Penggorengan}

Pemanas, Kabel, dan Penggorengan adalah beberapa komponen pendukung yang dibutuhkan untuk aplikasi perancangan solar cell untuk penerangan. Lampu dab kabel merupakan beban yang memiliki besaran tergantung dengan besar daya dan panjang kabel yang dibutuhkan. Tiang berguna sebagai penyangga pada panel modul Solar Cell.

\section{METODELOGI PENELITIAN}

\subsection{Pemilihan Data Komponen dan Alat}

Pemilihan data komponen berdasarkan tingkat kebutuhan rancangan pada alat induction heating dan alat solar cell sesuai dengan kebutuhan. Komponen-komponen yang dibutuhkan meliputi komponen dasar, komponen utama, dan komponen pendukung.

\section{A. Komponen Dasar}

Komponen - komponen dasar meliputi resistor, kapasitor, dioda, LED, dan LCD.

\section{B. Komponen Utama}

Komponen utama meliputi sensor suhu, mikrokontroler Arduino Uno, sensor suhu dan modul solar cell meliputi papan solar cell, baterai penyimpanan berupa aki dan konverter sebagai perubahan tegangan.

\section{Komponen Pendukung}

Komponen pendukung komponen meliputi indikator tampilan dan indikator suara. Sedangkan komponen pendukung alat adalah tiang penyangga untuk instalasi solar cell.

\subsection{Jalannya / Alur Pikir Penelitian}

Adapun tahapan dalam penelitian ini diilustrasikan pada gambar 10 . 


\section{HASIL DAN PEMBAHASAN}

4.1. Perancangan Rangkaian Heater

Dalam perancangan rangkaian heater sebagai pemanas dengan menggunakan jenis Tubuler Heater. Jenis heating berbentuk tabung digunakan untuk aplikasi pengolahan oven pengering. Untuk bentuk tekukan dan daya disesuaikan dengan kebutuhan.

\subsection{Perancangan Alat Induction Heating}

Pemanas induksi atau yang bisa disebut juga induction heating adalah sebuah alat atau rangkaian yang mampu menghasilkan panas dan memanaskan benda dengan sistem induksi. Benda yang dipanaskan tersebut mendapatkan sumber panas dari induksi medan magnet yang sangat cepat, panas bukan berasal dari sebuah elemen pemanas yang panas ketika diberikan sumber tegangan. (Purnomo \& Hari 2014).

Perancangan Alat induction heating dengan menentukan rangkaian - rangkaian yang nantinya akan dibutuhkan dalam proses induction heating meliputi yaitu : rangkaian pemanas / heater, rangkaian pembagi tegangan, rangkaian penguat, rangkaian power Suppy dan rangkaian penampil sebagai Indikator tingkat panas yang dibutuhkan. Dengan keluaran panas mencapai $80^{\circ} \mathrm{C}-100^{\circ} \mathrm{C}$.

\subsection{Perancangan Alat Solar Cell}

Perancangan alat solar cell dengan membuat rangkaian penyimpan Daya sesuai dengan kapasistas yang dibutuhkan dalam proses Induction Heating. Dengan spesifikasi dibutuhkan 2 papan solar cell (200 W untuk tiap papannya), Sebagai penyimpan dayanya menggunakan Aki 100 A, $12 \mathrm{~V}$.

\subsection{Analisis Hasil Perancangan Alat}

Untuk mendapatkan hasil penelitian yang dapat dipertanggung jawabkan, maka analisis hasil penelitian ini dilakukan dengan menghitung nilai daya yang dibutuhkan untuk menghidupkan pemanas selama rentan waktu yang dibutuhkan. Semakin lama waktu pemanasan dibutuhkan daya yang lebih besar yang dapat ditampung oleh baterai atau aki. Estimasi perhitungan perhitungan dapat dilihat pada tabel 1 .

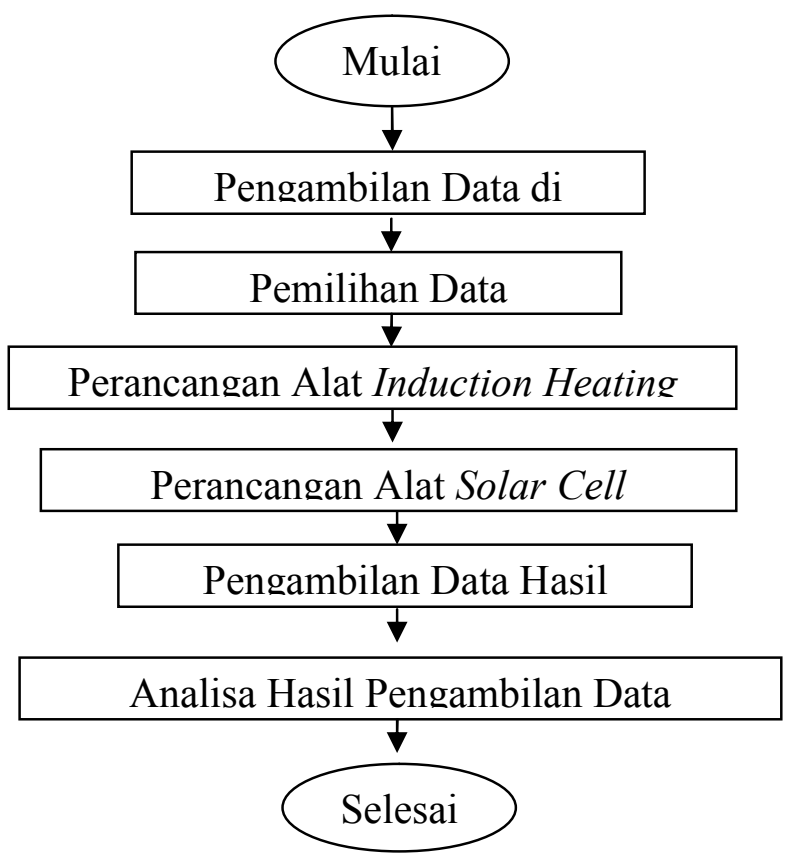

Gambar 10. Bagan Alur Penelitian. 
Tabel 1. Analisa Hasil Perancangan Alat

\begin{tabular}{c|c|c|c|c|c|c}
\hline No & $\begin{array}{c}\text { V } \\
\text { Baterai/Aki } \\
\text { (Volt) }\end{array}$ & Jml Aki & $\begin{array}{c}\text { Arus } \\
\text { (A) }\end{array}$ & $\begin{array}{c}\text { Daya Keluaran } \\
\text { Aki } \\
\text { (WH) }\end{array}$ & $\begin{array}{c}\text { Solar } \\
\text { Panel } \\
\text { (W) }\end{array}$ & $\begin{array}{c}\text { Estimasi } \\
\text { max } \\
\text { pemakaian } \\
\text { waktu } \\
\text { (Jam) }\end{array}$ \\
\hline 1 & 12 & 8 & 7,2 & 691,2 & 250 & 3 \\
2 & 12 & 12 & 7.2 & 1036,8 & 500 & 5 \\
\hline
\end{tabular}

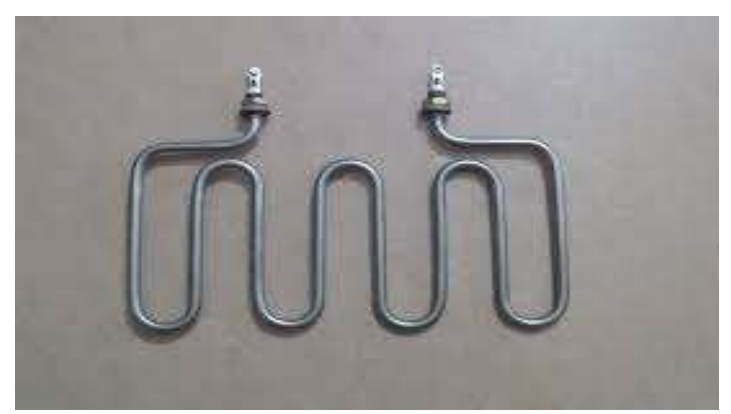

Gambar 11. Tubuler Heater.

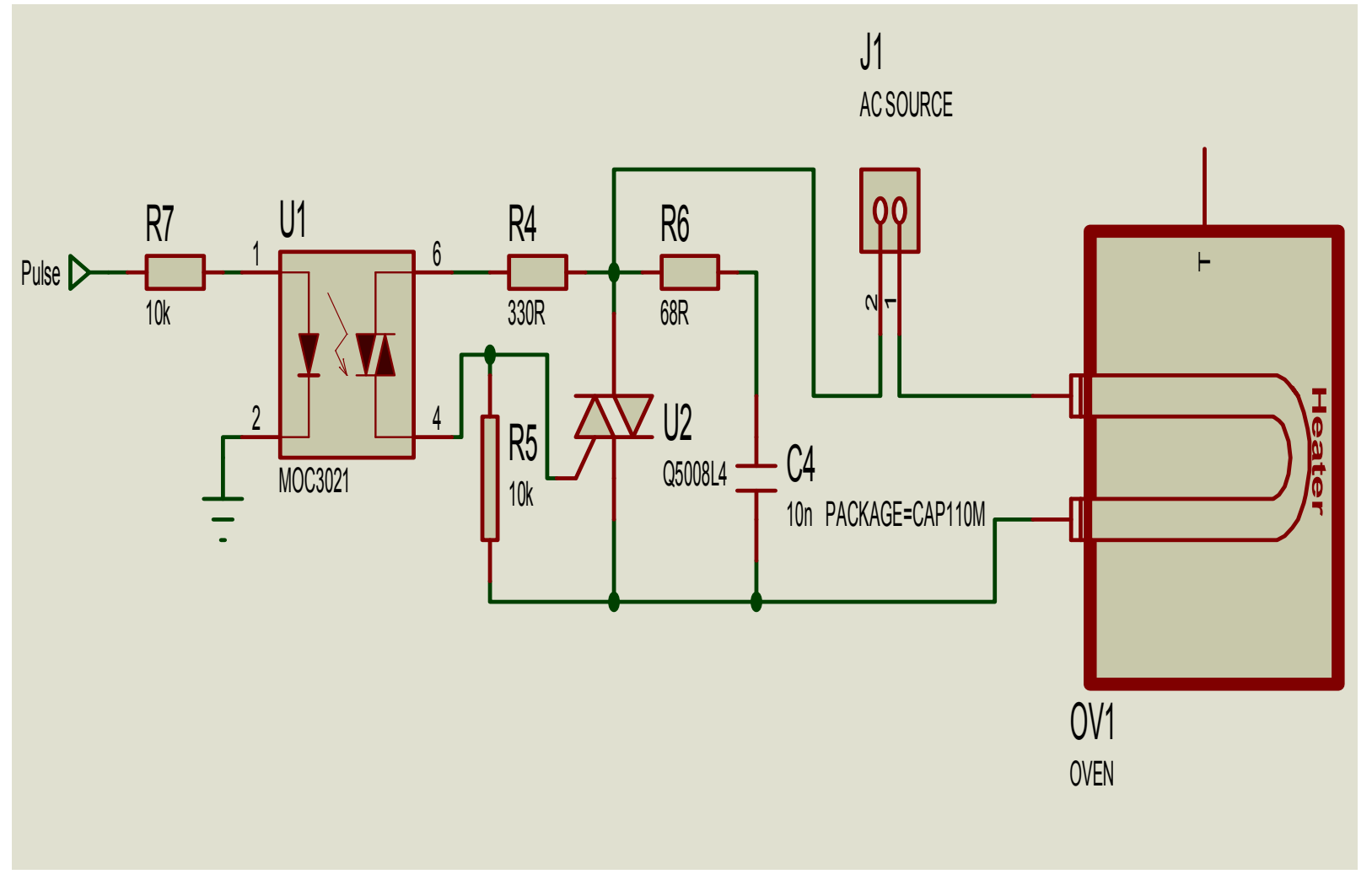

Gambar 12. Rangkaian Heater. 


\subsection{Perancangan Alat Keseluruhan}

Solar Cell Paralel

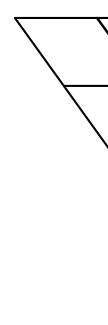

Solar Cell Parale

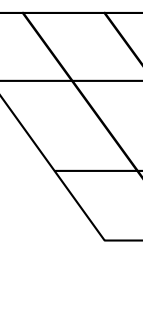

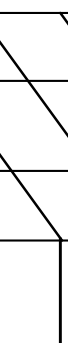

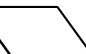

9

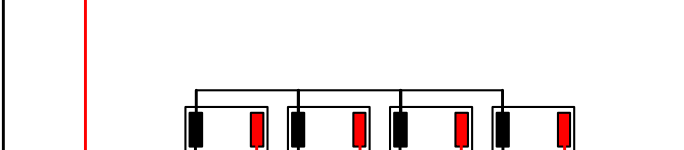

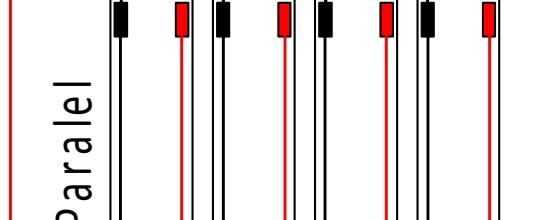

PWM Control

Wajan Pemanas

Solar Cell
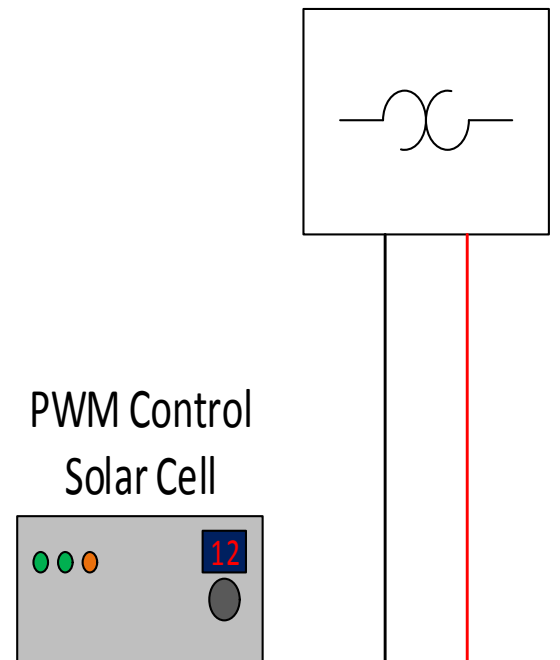

\subsection{Pengolahan Data}

Pengolah data dilakukan dengan pengambilan data uji setiap rangkaian yang digunakan dalam perancangan induction heating dan pada modul perancangan solar cell.

\subsection{Analisis Pengolahan Data}

Analisa data yang dilakukan adalah dengan menghitung tingkat kebutuhan daya, nilai efisiensi dan jumlah muatan panas yang dihasilkan oleh induction heating. a. Menghitung Efiesiensi Panel Surya

Efisiensi dari panel dihitung adalah dengan membagi output daya sel (dalam watt) pada maksimum powerpoint $(\mathrm{Pm})$ oleh cahaya masukan (E, dalam $\mathrm{W} / \mathrm{m}^{2}$ ) dan luas permukaan sel surya (Ac di $\left.\mathrm{m}^{2}\right)$.

$\eta=\operatorname{Pm} /(\mathrm{E} \times \mathrm{Ac})$

Perhitungan efisiensi dalam suatu sistem yang dirancang untuk menyerap energi sebesar $200 \mathrm{~W}$ dengan menggunakan area $1,5 \mathrm{~m} 2$. 
Dalam hal ini kita akan menggunakan nilai Indicent Radiation Flux sebesar 1000 $\mathrm{W} / \mathrm{m} 2$ (berarti untuk setiap $\mathrm{m} 2$ matahari mampu memberikan daya sekitar 1000 Watt). Lalu perhitungannya akan menjadi sebagai berikut :

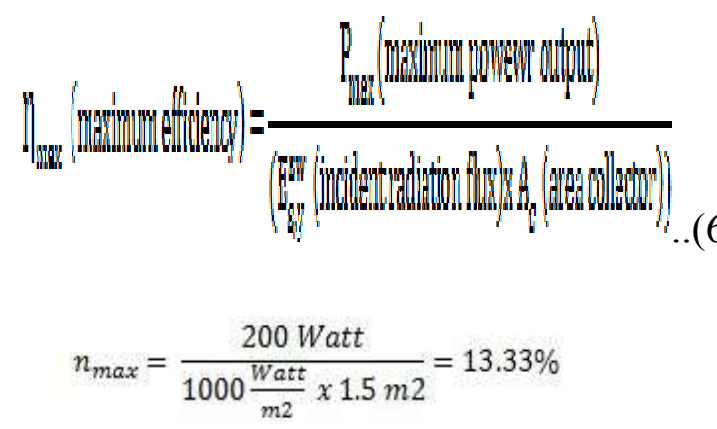

b. Menentukan Jumlah solar cell yang digunakan

Jumlah solar cell panel yang dibutuhkan, satu panel kita hitung 100 Watt (perhitungan adalah 5 jam maksimun tenaga surya), tingkat kebutuhan solar cell panel dapat dihitung $=(3480 / 100 \times 5)=7$ panel surya. Jumlah kebutuhan baterai 12 Volt dengan masing - masing 100 Ah. Kebutuhan baterai minimum (baterai hanya digunakan 50\% untuk pemenuhan kebutuhan listrik).

Perhitungan tingkat kebutuhan daya yaitu :

$=$ dikalikan $2 \times$ lipat.

$=3480 \times 2=6960$ Watt hour.

$=6960 / 12$ Volt $/ 100$ Amp.

$=6$ baterai $100 \mathrm{Ah}$.

Kebutuhan baterai (dengan pertimbangan dapat melayani kebutuhan 3 hari tanpa sinar matahari).

$=3480 \times 3 \times 2$.

$=20880 \mathrm{Watt}$ hour.

$=20880 / 12$ Volt / 100 Amp.

$=17$ baterai $100 \mathrm{Ah}$.

c. Menghitungan pemakaian daya listrik berdasarkan volume media dan jenis media yang akan dipanaskan.
$\mathrm{Q}=\mathrm{M}$ Cp DT kalori

Dimana :

$\mathrm{Q}=$ Jumlah Panas (kal)

$\mathrm{M}=$ Massa Benda (gram)

DT $=$ Perbedaan Suhu (derajat Celcius ).

$\mathrm{Cp}=$ Conduktifitas thermal $(\mathrm{Kal} / \mathrm{Gram} \mathrm{C})$.

$1 \mathrm{~W}=1 / 800$ Kalori

Rumus Induction Heating :

Persamaan daya sebagai berikut :

(1) Peddy total $=9,61967 \times 10^{-4} \times \pi^{3}{ }_{x} t^{2} \mathrm{xb} /$ p. $Z_{\text {coil }}^{2}$ (Watt).

(2) Energi yang dibutuhkan oleh pemanas induksi selama waktu $t$ adalah :

$\mathrm{W}=$ Peddy total $\mathrm{x} \mathrm{t}$ (Joule)

(3) Energi yang dibutuhkan oleh pemanas induksi dari suhu T1 sampai T2 adalah : $\mathrm{Q}=\mathrm{m} \times \mathrm{c}$. (T2 - T1) (Joule)...

(4) Kemudian besarnya efisiensi energi dapat dihitung sebagai berikut : $\eta=\mathrm{Q} / \mathrm{W}_{\text {in }} \times 100 \%$

\section{KESIMPULAN}

1. Dalam perancangan alat induction heating dengan menggunakan sumber energi dari matahari melalui panel solar cell. Dari panel solar cell tersebut daya disimpan dalam baterai / aki kering melalui solar charger controller. Daya yang digunakan pemanas diambil dari baterai / aki. Baterai atau Aki sebagai penyimpan daya dengan kapasitas 12 Volt 7,2 Ah dirangkai paralel untuk mendapatkan daya yang dibutuhkan oleh pemanas sebesar 300 Watt. Daya dari hasil rangkaian seri aki sebesar 691,2 Watt hour.

2. Dari hasil perancangan alat bergantung dengan tingkat kebutuhan daya pada pemanas untuk sangrai daun teh. Suhu yang dibutuhkan antara $80^{\circ} \mathrm{C}$ sampai dengan $100^{\circ} \mathrm{C}$. Lama waktu pemanasan dibutuhkan kira - kira dalam waktu 3 jam. 


\section{DAFTAR PUSTAKA}

Ady Iswanto., 2008. Prinsip Dasar Solar Cell, Staf Divisi Riset 102FM ITB, Bandung.

Faslucky., 2012. Optimalisasi tegangan keluaran dari Solar Cell Menggunakan Lensa Pemfokus Cahaya Matahari. Malang.

Novinasyah, R., 2012. Pemanas Induksi (Induction Heating) Kapasitas 200 Watt. Jurusan Teknik Mesin Universitas Gunadarma.

Owen Bishop, 2004. Dasar - dasar Elektronika, Erlangga, Jakarta.

Purnomo \& Hari M., 2014. Konsep Dasar Teknik Elektronika Kelistrikan. Penerbit Alfabeta, Bandung.

Yossie,W., 2013. Prototype Pemanfaatan Solar Cell Sebagai Sumber Energi Pada Sistem Otomatisasi Lampu Penerangan Taman, Universitas Negeri Yogyakarta. 